\title{
CHANGES IN VIEW ON FINANCIAL POSITION AND PERFORMANCE OF A COMPANY AT APPLICATION OF THE IFRS IN THE CZECH REPUBLIC
}

\author{
Michaela Beranová ${ }^{1}$, Josef Polák ${ }^{2}$ \\ ${ }^{1}$ Brno University of Technology, Faculty of Business and Management, Kolejní 2906/4, 612 00 Brno \\ Email: beranova@fbm.vutbr.cz \\ ${ }^{2}$ Brno University of Technology, Faculty of Business and Management, Kolejní 2906/4, 612 00 Brno \\ Email: polakj@fbm.vutbr.cz.
}

\begin{abstract}
Financial statements are a necessary base of measurement of financial position and performance of a company, and the clearly proved fact is that the view on financial position and performance is influenced by applied accounting and reporting methods. Objective of the submitted paper is to quantify differences in financial position and performance of companies at application of IFRS. The authors are also aimed at the synthesis of accounting differences between IFRS and the Czech accounting law. In order to fulfil objective of the paper the authors based their work especially on the primary research. They have used the statistic sample of companies where they transformer financial statements of these companies in accordance with the IFRS. Then, the methods of financial analysis have been applied in order to quantify the differences in the financial position and performance at application of the IFRS.
\end{abstract}

Keywords: financial performance, financial position, IFRS, true and fair view.

JEL classification: M21, M41

Doručeno redakci: 7.2.2013; Recenzováno: 10.5.2013; 10.5.2013; Schváleno k publikování: 11.9.2013

\section{Introduction}

During the last century, international exchanges of every kind were growing, under the final domination of the USA. Recently, a more global market needs an international accounting system to enforce economic development and competition (Beranová \& Cudel, 2007). Global market objectively needs a global accounting system, especially in order to increase economic development and the international competitiveness of companies.

Concurrent behaviour of management of many companies is declared to be based on principles of corporate governance which is the set of processes, patterns, principles, rules and bodies which affect the manners of company's management while an indivisible part of the corporate governance is also the relation between objectives of stakeholders and company's objectives. The interest on corporate governance has taken effect, respectively has been growing, since 2001. It was especially because of the cases of great companies' bankrupts, Enron and WorldCom included. In the consequence of these events, Sarbanes-Oxley Act was introduced in 2002. This document should restore a public confidence in the corporate governance.

It is obvious that in this point of view, it is not possible to eliminate the question of financial reporting. From this side, the corporate governance may be defined by the scheme 1 . These schematically drawn terms form the background of current basis of financial accounting that should ensure the really true and fair view of financial position and performance of a company with the aim to enable managers as well as the company's environment to make rational economic decisions. Based on this background, it is possible to say that the fair value is currently perceived as some top of the financial reporting pyramid. But at the same time, it 
is necessary to say that this "top" is very disputable; very recently, the opinions (e.g. Beranová, 2008; Cairns, 2010; Casabona \& Shoaf, 2010; Mackintosh, 2008) that application of accounting principles using the fair value have taken the part in the financial crisis have appeared.

Figure 1: Key Word of Present Financial Reporting

Fair Value

+ Ethics

+ Due Process

+ Sustainable Development

$+\quad$ Mutual Understanding

$\Sigma$ Corporate Governance

Source: Elaborated based on Tweedie (2007)

\section{Aim of the Paper and Methodology Applied}

Up to the year 2005 the most of European companies based their financial statements on the national accounting standards. Introduction of the International Financial Reporting Standards (IFRS) in the frame of all the European Union and compulsory application of IFRS on financial reporting of EU listed companies then represent the greatest change in financial reporting in the last years.

Company's accounting, respectively the outcomes of accounting - financial statements are necessary base of its financial position and performance evaluation. It is clearly proved fact that applied accounting methods substantially influence the view on financial position and performance of a company (see e.g. Hope et al., 2005; Šteker \& Otrusinová, 2012; Taulea, 2009).

The objective of the submitted paper is to present quantification of differences in financial position and performance at application of the International Financial Reporting Standards (IFRS). These differences have been defined especially based on the primary research realized on the statistic sample of 50 companies from South-Moravian Region and Region of Zlín.

Financial statements of these companies prepared under the Czech accounting law have been adjusted in accordance with the requirements of IFRS. Special stress was put on the problem of financial leases where reporting differences and subsequent changes in the view on company's financial position and performance are tangible for the most. After, relevant methods of financial analysis, especially the ratio analyses are used in order to quantify an influence of IFRS application on evaluation of company's performance.

Besides the methods of financial analysis the relevant statistic methods are applied as well. The purpose of application of statistic methods is to generalize the results obtained, i.e. especially means and deviations have been calculated.

Another aim of the paper is the synthesis of difference between the International Financial Reporting Standards and the Czech accounting law. Regarding the number of differences between the IFRS and each national accounting standards it is not possible to involve every single one difference in one article. Then the authors focus on general problems and areas discussed within which the problem of Fair Value Accounting may currently be the most important. 


\section{Financial Reporting Based on the Fair Value}

Since the first half of the nineties, IASB and FASB have systematically replaced the measurement of balance sheet items in initial cost with measurement in market price, i.e. in fair value, starting with the specific remedy for the inequities of the reporting model for certain financial instruments. Later, the market-based measures have been increasingly implemented also for non-financial items, e.g. for investment property under IAS 40 (Hitz, 2007).

Reporting, or precisely measurement of the items that is based on initial cost is declining. It is pointed out by a range of authors (see e.g. Casabona \& Shoaf, 2010; Power, 2010; Cairns, 2010; Mackintosh, 2008) that relatively new models of market-based measurement are increasing as well as event-based measurement which have substantial effects on items in balance and on the accounting profit.

In accordance with the IFRS, the fair value is defined as the amount that an asset can be exchanged for or a liability can be settled for in orderly transaction between informed and willing parties in an arm's length transaction. Within the IFRS, three models of revaluation on the fair value exist. These are:

- Balance Model where the revaluation on fair value is charged directly to equity;

- Fair Value Model, i.e. revaluation on the fair value that immediately affects the profit of a company;

- Revaluation model as a combined revaluation while increase in fair value is charged to equity as a revaluation reserve, and decrease in fair value is recognised as a cost that affects the profit.

In US GAAP, the fair value is defined in the standard SFAS 157. There the fair value is understood as an exit value which is the price that would be received to sell an asset or paid to transfer a liability in orderly transaction between market participants at the measurement date. Definition applied here states that the fair value measurement assumes "the highest and the best use" on the asset, i.e. the use that would maximize the value of the asset, regardless the intended use of the asset by reporting entity (Mackintosh, 2008).

The fact is that the most of non-financial institutions have very few, if any, assets or liabilities that are measured at fair value at each balance sheet date. Even in the case of banks, fair value measurement often affects less than 10 per cent of assets and an even smaller proportion of liabilities. This is especially because the IFRS limit the mandatory measurement at fair value to those financial assets that are held for trading purposes, other equity investments and other derivatives. In practice, the most banks' financial statements are still dominated by loans and receivables and customer and inter-bank deposits which continue measurement at cost. It means that fair value measurement option for these items is used rarely (Cairns, 2010). Notwithstanding, the problem is that fair value measurement leads to inclusion of unrealised profits in the total profit of a year. The total profit is overestimated then. Undoubtedly, it is rather heavy pain consequently causing a failure of the top requirement on financial reporting, i.e. a failure of the true and fair view on the financial performance of reporting entity.

In their works, various authors (e.g. Lantto \& Salström, 2009; Barth et al., 2008; Bartov et al., 2005; Daske \& Gebhardt, 2006) focus on the question if the IFRS adoption really provides better quality of financial reporting. At the same time, these authors refer to the fact that differences in national accounting standards substantially affect the quality of financial reporting as well. Even though, the literature does not determine which domains of 
differences have the most important impact on the reported items and this way on the financial indicators that are calculated based on reported values.

Adoption of the IFRS as of some integrating element of financial reporting of public traded companies in the EU member states is generally perceived to improve the transparency and comparability of financial statements between EU listed companies. Member states are likely to adopt the IFRS or implement them into their national accounting standards in order to improve investor protection, to make their capital market more accessible to foreign investors and to improve the comparativeness and comprehensiveness of the financial information (Hope et al., 2005). Some studies also point out that adoption of IFRS improves the quality of accountancy of the EU listed companies (Barth et al., 2008).

In the literature focused on classification of accounting systems (e.g. d'Arcy, 2001), two major directions of accounting standardization have been observed. These are European cluster and North American cluster while the North American cluster is more oriented to capital market and investors, and that is why it includes also IASB. Based on this, Nobes (2001) has defined two main reasons of differences between IFRS and national accounting standards. These differences consist in comprehensiveness and capital market orientation.

The problem of comprehensiveness arises from some inconveniences in national accounting standards because national accounting standards do not cover all the rules that are included in the IFRS or these rules are only optional under the national accounting standards. Other question is strength of interconnection between accounting and the tax regulation (Näsi \& Virtanen, 2005).

In the frame of the Czech accounting system, it is possible to find fundamental differences in comparisons to IFRS. These differences consist especially in following domains:

- Leases (IAS 17);

- Intangible Assets (IAS 38);

- Employees Benefits (IAS 19);

- Construction Contracts (IAS 11);

- Share-based Payments (IFRS 2).

Moreover, the areas where the use of fair value is required under IFRS form other domains of differences between IFRS and Czech accounting law. IFRS require/allow fair value measurement/accounting in the following areas:

- Property, Plant and Equipment (IAS 16);

- Impairment of Assets (IAS 36);

- Financial Instruments (IAS 39/IFRS 7);

- Investment Property (IAS 40);

- Biological Assets (IAS 41);

and also in categories of employees' benefits, respectively pension assets and liabilities, and share-based payments mentioned in previous paragraph.

Entering the financial leases in accounting is the typical example from the Czech accounting law which documents that the formal side is still preferred to the content. (Beranová et al., 2010) In this area, the accounting rules for financial leases are completely different not only from the rules under IFRS but also from the rules of the most EU countries, Slovak Republic included. While the payments of financial lease are accounted as costs under the Czech accounting law, under IFRS the property covered with the financial lease is recognized as an 
asset, and over this asset, long-term liability is recognized and decreased according to the lease payments. As costs affecting the profit only depreciation of the asset and interest related to the long-term liability are accounted. It is obvious that this approach has substantial influence on the profit, on the amount of fixed assets and subsequently on the total assets, on the sum of long-term liabilities and consequently on total capital, which are the crucial inputs of the most economic analyses. If an ordinary potential investor would like to make relevant analysis of a company reporting under the Czech accounting law, all the property under financial leases is hidden to him/her.

In the area of intangible assets, the standard IAS 38 relatively strictly states that an intangible asset shall be recognized only when it will probably entail future economic benefits and when the cost of this asset can be measured reliably. The first problematic point that appears under the Czech accounting law is the recognition of company's set-up costs as the intangible asset. IAS 38 emphasizes that these expenses shall not be recognized as an asset but have to be accounted for costs of the period when these expenses were realized. In this context a disagreement could appear in the question of the "future economic benefits". From some point of view, the set-up costs might be understood as the amounts that have to be spent in order the asset - company would start to exist, and as the future economic benefits future profits of a company could be perceived. But this point of view collides with the probability of the future economic benefits that have to be "more likely than not". In this case, the potential asset is not measured reliably neither. Then it is possible to suppose that recognition of set-up costs as the intangible asset leads to overestimation of total assets. This affects the overall view on company's financial position again.

The goal of standard IAS 38 is to minimize risks connected with recognition and measurement of the intangible assets. But this cannot be stated in frame of the Czech accounting legislation where the problem is handled rather shallow. The main differences arise from the approach to recognition and measurement of intangible assets under the Czech accounting law. Within the question of recognition, one of the greatest differences is treatment with goodwill. Under the Czech accounting law, goodwill is always amortized, and the amortization is for five years. In this consequence, there is another problem which consists in impossibility to recognize a new intangible asset at business entity acquisition. Disputable is also the area of internally generated intangible assets. According to the Czech accounting law, intangible assets generated for the internal needs of a company are recognized only as costs in the period when they have been spent. This can affect the amount of profit substantially in more than one accounting periods. Therefore the view on financial position and performance of a company is affected again. Another question about intangible assets is the amounts spent on research and development. As a basis for reasoning, the future economic benefits which are "more likely than not" are considered. Related to the IFRS, the cost of research may not be capitalized and these amounts are reported as costs. Capitalization of the amounts spent in the stage of development is then contingent on a range of premises fulfilment. Accounting solution of the cost of research and development in the Czech Republic is relatively wide and variable. It is especially because of the taxation rules connected with these expenses. If the items of research and development should be recognized as an asset under the Czech GAAP (i.e. in balance sheet item "Intangible Results of Research and Development"), it have to be result of R\&D which is successfully finished while this result ${ }^{1}$ :

\footnotetext{
${ }^{1}$ According to the Code no. 500/2002 which explains some rules given by the Accounting Law no. 563/1991; $\S 6$, article 3 , letter b) in the accepted text of the law.
} 
- is generated internally in order to trade them repeatedly, or

- is purchased separately, i.e. it is not a part of purchase and measurement of fixed assets.

In the domain of the intangible assets it is possible to measure an intangible asset at the fair value in no case under the Czech accounting law. On the other hand, the fair value accounting is accentuated within the IFRS which are oriented on the capital market. It is especially because of the fair value incorporates more information into the financial statements and makes the statements more useful to potential investors (Lantto \& Sahlström, 2009). This can be regarded as an approximation of accounting data to economic data. Therefore, the IASB considers and emphasizes fair value to be the most relevant measurement basis.

Fair value accounting is closely connected with recognition of the impairment losses. These categories are unknown under the Czech accounting law which is based on historical costs. In accordance with the Czech accounting standards, revaluation on the fair value is applied only on some chosen financial instruments. Related to the changes in assets value under the Czech accounting law, only decrease in the value is recognized through a value adjustment. In fact, even if adjustment is recognized, in the accounting books historical costs are still kept because this adjustment is booked and reported separately from given asset's item.

Substantial differences between accounting entries and the economic reality exist also in other domains; especially in those mentioned above. Causes of these differences are possible to be found in different historical movements of countries which have undoubtedly stigmatized the economic way of thinking and the paradigms forming the bases of accounting systems, not only in the Czech Republic. Then these differences exist on the continental level as well.

\section{Quantification of Differences in Financial Position and Performance}

Impact of accounting differences, i.e. differences between the Czech accounting law and the IFRS, is visible already from the change in the balance sheet sum. In average, the balance sheet sum increased by $1.1 \%$. This change is caused especially by involving property under financial leases to the balanced fixed assets. Average increase observed is not very high but changes in single items of assets, liabilities and equity are more tangible in the results of ratio analyses.

With transformation of financial statements the profit/loss of a company has been changed substantially. Then, this change has a great impact on the analysis of profitability when the ratio of Return on Assets (ROA) increased by $28.57 \%$ in average, average increase in the Return on Equity has been $33.35 \%$, and Return on Sales has increased by $30.91 \%$ in average. This way, the average results of analysis of profitability are higher by $32.34 \%$.

The transformation of financial statement has caused the decrease in result of liquidity ratios. These ratios decreased by $5.31 \%$ in average while the most visible decrease is connected with the current ratio. Results of current ratio in the analysed companies have decreased by 10.53 $\%$ in average. In connection with the results of profitability ratios it is possible to conclude with demonstration of the theoretical premise about contradictory relation between liquidity and profitability.

Similar analyses have been made by the Finish authors Lantto \& Sahlström (2009). These authors observed e.g. the average increase in profitability by $9-19 \%$ and decrease in liquidity by $0.1-0.2 \%$ in average. These authors have also focused on the indicators of the 
capital market while they have identified the average decrease in the P/E Ratio by $11 \%$. The group of the capital market indicators are not applicable on the analysed company for the objective reasons arisen from the general circumstances of the Czech Republic and particular circumstances of analysed companies.

\section{Conclusion}

With regard to the identified differences in financial reporting under the Czech accounting law and under the IFRS it is necessary to formulate adjustments or modification of definition of entering variables. These variables are especially EBIT (Earnings before Interest and Tax) and NOPAT (Net Operating Profit after Taxation). This necessary modification comes out from the different comprehension of "operating activities" in the Czech accounting law and in the IFRS and in the US GAAP as well. In such a context, first of all it is inevitable to identify non-operational assets and financial resources (equity or liabilities) matching to these assets, and also all costs and revenues connected with these non-operational assets. Unfortunately, it is not possible to provide a general recommendation in this area. Objectively, it is necessary to presuppose case by case because non-operational assets in one company would not be nonoperational in other companies.

Deflection from the historical costs and the shift to fair value accounting reflects the economic approach to measurement in accounting, i.e. an effort to report economic data instead of the accounting ones which are often far from true economic reality. Many indicators of the financial health of a company ${ }^{2}$ require transformation of accounting figures into economic data. In his work, Hitz (2007) also points out a fact that fair value measurement eliminates hidden reserves and contributes to reduction of the gap between accounting value of a company and market value of its equity.

It is obvious that because of the conceptual reasons application of the fair value accounting is not able to entirely eliminate the problem of a difference between accounting and market value of a company. The domains where asset recognition is prohibited exist there; these are for example internally generated assets and the factors of internally generated goodwill. But objectively it is possible to suppose that these gaps of the financial reporting are still more positive than negative especially in the connection of the WorldCom affair. In the Czech environment, indispensable problematic aspect is the sole relevant fair value estimation because for the most property items no effective market exists. On one hand, allowance of the fair value measurement in greater extent would lead to approximation of the financial statements to the economic statements of a business entity, but on the other hand, it would also increase a danger of distortion, especially in the sense of overestimation of the financial position and performance of a reporting entity.

\section{References}

[1] BARTH, M. E., W. LANDSMAN and M. LANG, 2008. International Accounting Standards and accounting quality. Journal of Accounting Research, Vol. 46, pp. 467-498.

[2] BARTOV, E., S. GOLDBERG and M. KIM, 2005. Comparative value relevance among German, U. S. and International Accounting Standards: a German stock market perspective. Journal of Accounting, Auditing and Finance, Vol. 20, pp. 95-119.

[3] BERANOVÁ, M., 2008. Adoption of IFRS/IAS impacting the Companies. Trendy ekonomiky a managementu, č. 3, s. 27-33. ISSN 1802-8527.

\footnotetext{
${ }^{2}$ For example the Economic Value Added (EVA)
} 
[4] BERANOVÁ, M., M. BASOVNÍKOVÁ a D. MARTINOVIČOVÁ, 2010. Problematic Aspects of the Economic Value Added Measure in Environment of the Czech Republic. Acta universitatis agriculturae et silviculturae Mendelianae Brunensis, LVII, No. 6. ISSN1211-8516.

[5] BERANOVÁ, M. and F. CUDEL, 2007. IFRS/IAS: International Financial Reporting Standards Current and Future Impacts on Companies. Buchgaltěrskij učet, analiz i audit: istoria, savremennost' i perspektivy razvitija. ENGECON - St. Petersburg State University, pp. 4-9, ISBN 978-5-88996-823-8.

[6] CAIRNS, D., 2010. Accounting standards and the financial crisis. Accountancy magazine, March 2010, p. 67. [On-line] http://www.accountancymagazine.com/

[7] CASABONA, P. and V. SHOAF, 2010. Fair Value Accounting and the Credit Crisis. Review of Business, Vol. 30, pp. 19-30.

[8] DASKE, H. and G. GEHARDT, 2006. International financial reporting standards and experts' perceptions of disclosure quality. Abacus, Vol. 42, pp. 461-498.

[9] d'ARCY, A., 2001. Accounting classification and international harmonization debate an empirical investigation. Accounting Organization and Society, vol. 26, pp. 327-349.

[10] HITZ, J. M., 2007. The Decision Usefulness of Fair Value Accounting - A Theoretical Perspective. European Accounting Review, Vol. 16, No. 2, pp. 323-362.

[11] HOPE, K. O., J. JIN and T. KANG, 2005. Empirical evidence on jurisdictions that adopt IFRS. Journal of International Accounting Research, Vol. 5, pp. 1-20.

[12] LANTTO, A. M. and P. SAHLSTRÖM, 2009. Impact of International Financial Reporting Standard adoption on key financial ratios. Accounting and Finance, Vol. 49, pp. 341-361.

[13] MACKINTOSH, I., 2008. Measurement: does the difference matter? Accountancy magazine, September 2008, pp. 88-89. [On-line] http://www.accountancymagazine.com/

[14] NÄSI, S. and A. VIRTANEN, 2005. The European Accounting Guide: Chapter 5: Finland, $3^{\text {rd }}$ ed., Garhersburg, Aspen Publishers.

[15] NOBES, C. W., 2001. GAAP 2001 - A Survey of National Accounting Rules Benchmarked Against International Standards. [On-line] http://www.iasplus.com/resource/gaap2001.pdf

[16] ŠTEKER, K. a M. OTRUSINOVÁ, 2012. Accounting Information as the Framework for Management. Acta academica karviniensia, č. 3, s. 139-150. ISSN 1212-415x.

[17] TAULEA, S., 2009. The consequences of accounting standardization and harmonization over the concept of financial position. Annals of the University of Petrosani, Economics, Vol. 9 (4), pp. 283-288.

[18] TWEEDIE, D., 2007. Can Global Standards be Principle Based? Journal of Applied Research in Accounting and Finance (JARAF), Vol.2, No.1, pp. 3-8. [On-line] http://ssrn.com/abstract=1012241 